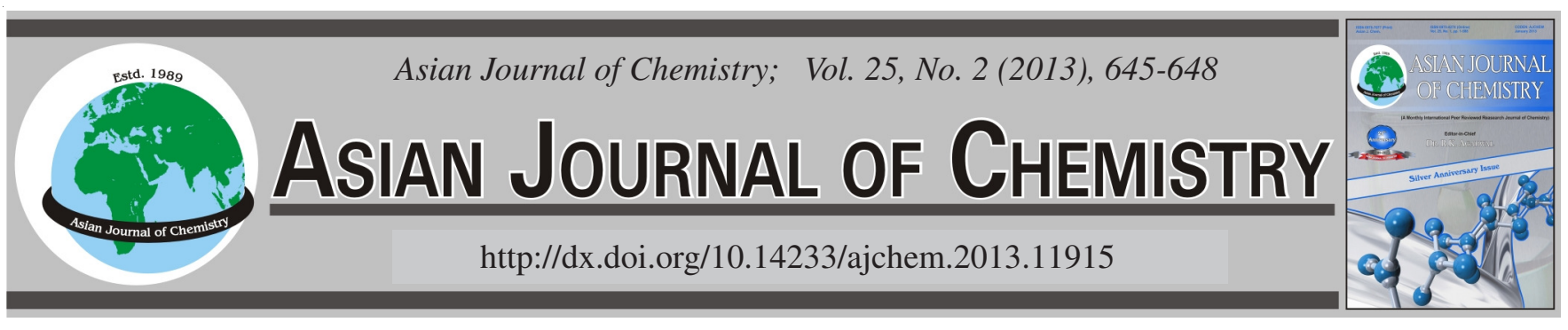

\title{
Tbfmoc Methioine: Its Synthesis and Application for the Solid Phase Synthesis and Purification of Ubiquitin C-Hydrazide
}

\author{
Q. Liu, Z. Jin, N.F. Hu and P. WANG*
}

School of Pharmaceutical Science, Shandong University, Jinan 250012, Shandong, P.R. China

*Corresponding author: Tel: +86 531 88382005; E-mail: puwang@sdu.edu.cn; qiangcun.cool@163.com

The new reagent Tbfmoc-Met-OH is synthesized and used as a building block to replace Fmoc-Met-OH for the solid phase synthesis of ubiquitin C-hydrazide, an unnatural protein containing 76 amino acids and bring the Tbfmoc group into the synthetic product efficiently. The attached Tbfmoc group can provide good help for the product separation and improve the purification efficiency significantly.

Key Words: Tbfmoc methioine, Ubiquitin C-hydrazide, Protein separation and purification.

\section{INTRODUCTION}

Ubiquitin (H-Ub-OH, Fig. 1), a protein containing 76 amino acids, plays important roles in various cellular functions, which include cell-cycle regulation, DNA repair, cell growth, signaling and immune function ${ }^{1-4}$. When the C-terminal of an ubiquitin connects with the $\varepsilon-\mathrm{NH}_{2}$ of $\mathrm{Lys}^{48}$ in another ubiquitin molecule, diubiquitin can be produced and show distinct functions such as proteasomal degradation and cell signaling in diverse biological process ${ }^{5,6}$.

H-Met ${ }^{1}$-Gln-Ile-Phe-Val-Lys-Thr-Leu-Thr-Gly ${ }^{10}$-Lys-Thr-IleThr-Leu-Glu-Val-Glu- Pro-Ser ${ }^{20}$-Asp-Thr-Ile-Glu-Asn-ValLys-Ala-Lys-Ile ${ }^{30}$-Gln-Asp-Lys-Glu-Gly-Ile-Pro-Pro-AspGln $^{40}$-Gln-Arg-Leu-Ile-Phe-Ala-Gly-Lys ${ }^{48}$-Gln-Leu ${ }^{50}$-GluAsp-Gly-Arg-Thr-Leu-Ser-Asp-Tyr-Asn ${ }^{60}$-Ile-Gln-Lys-GluSer-Thr-Leu-His-Leu-Val ${ }^{70}$-Leu-Arg-Leu- Arg-Gly-Gly ${ }^{76}$-X Ubiquitin: $\mathrm{X}=-\mathrm{OH}$; ubiquitin C-hydrazide: $\mathrm{X}=-\mathrm{NHNH}_{2}$

Fig. 1. Sequence of ubiquitin and ubiquitin $\mathrm{C}$-hydrazide

Ubiquitin C-hydrazide (H-Ub-NHNH 2 , Fig. 1) is an important intermediate for diubiquitin synthesis. The $\mathrm{C}$-hydrazide group in $\mathrm{H}-\mathrm{Ub}-\mathrm{NHNH}_{2}$ can be transferred to azide or other active groups then connect with the $\varepsilon-\mathrm{NH}_{2}$ of $\mathrm{Lys}^{48}$ in another ubiquitin molecule to produce diubiquitin.

$\mathrm{H}-\mathrm{Ub}-\mathrm{OH}$ can be prepared through both biological engineering and solid phase peptide synthesis (SPPS) technologies, but preparation of $\mathrm{H}-\mathrm{Ub}-\mathrm{NHNH}_{2}$ faces big challenge. As an unnatural protein derivative, $\mathrm{H}-\mathrm{Ub}-\mathrm{NHNH}_{2}$ can't be prepared by biological engineering technology. The Fmoc SPPS method can be used for the synthesis of $\mathrm{H}-\mathrm{Ub}-\mathrm{NHNH}_{2}$, but the purifi- cation of the synthetic $\mathrm{H}-\mathrm{Ub}-\mathrm{NHNH}_{2}$ is very difficult after the synthesis completed.

(17-Tetrabenzo[a,c,g,i]fluorenyl)methylchlorformate (Tbfmoc-Cl (1) in Scheme-I) is a useful reagent for the rapid and efficient purification of synthetic polypeptides and proteins in SPPS $^{7-9}$. The Tbfmoc group is similar as the Fmoc group in some features: it can be used as a protecting group for amino, stable to acidic or neutral conditions and easy to be deprotected in mild basic condition ${ }^{10}$.

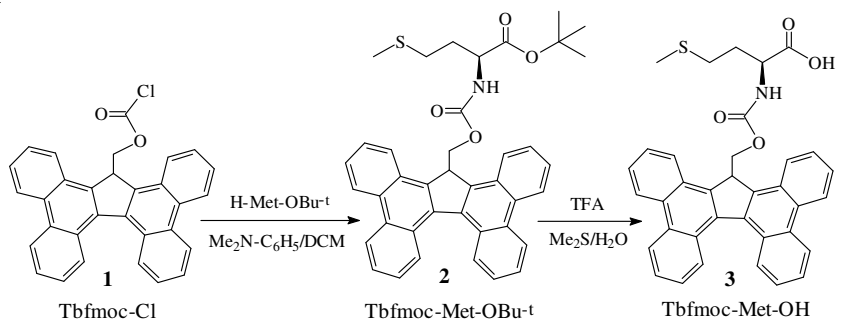

Scheme-I: Synthesis of Tbfmoc-Met-OH

The most important application value of Tbfmoc group is used as a special tool for the separation and purification of polypeptides and proteins synthesized with Fmoc SPPS method. When Tbfmoc group is loaded to the N-terminal of the peptide in SPPS, significant differences such as affinity to solid adsorbents and the UV absorbency can be produced between the Tbfmoc labeled sequence and the impurities that not connected with Tbfmoc group. The Tbfmoc labeled product has strong absorbance at $365 \mathrm{~nm}$, which can be detected easily with UV detector and identified from the impurities; the big 
planar structure of Tbfmoc group make the Tbfmoc labeled product be eluted faster than the no Tbfmoc labeled impurities during gel filtration and separated from the impurities efficiently.

When Tbfmoc-Cl was used for the purification of $\mathrm{H}-\mathrm{Ub}$ $\mathrm{NHNH}_{2}$, however, only unreliable results with low efficiency were obtained due to the following reasons: (i) loading Tbfmoc- $\mathrm{Cl}$ to the amino group at the $\mathrm{N}$-terminal of the resin bound ubiquitin $\mathrm{C}$-hydrazide derivative is quite difficult because $\mathrm{Tbfmoc}-\mathrm{Cl}$ shows very poor solubility in organic solvents and only low concentration can be obtained; (ii) the loading reaction has to be extended for a long time and increases Tbfmoc-impurities; (iii) both of the low loading efficiency and the increased Tbfmoc-impurities make the separation of Tbfmoc-Ub-NHNH$H_{2}$ become quite difficult.

To overcome the weakness of Tbfmoc- $\mathrm{Cl}$ and obtain $\mathrm{H}-$ Ub-NHNH${ }_{2}$ with high efficiency, H-Met-OH, the N-terminal amino acid in the ubiquitin $\mathrm{C}$-hydrazide sequence is used as the starting material to synthesize Tbfmoc-Met-OH ( 3 in Scheme-I) and then the synthetic Tbfmoc-Met-OH is used as the building block to replace Fmoc-Met-OH for the SPPS of $\mathrm{H}-\mathrm{Ub}-\mathrm{NHNH}_{2}$. Tbfmoc-Met-OH can play double-role to $\mathrm{H}-\mathrm{Ub}-\mathrm{NHNH}_{2}$ since it keeps the characteristics of the Tbfmoc group: firstly, it is a key building block in the SPPS of H-Ub$\mathrm{NHNH}_{2}$; secondly, it is a new efficient separation tool to increase the efficiency of separation and purification for the synthetic $\mathrm{H}-\mathrm{Ub}-\mathrm{NHNH}_{2}$.

\section{EXPERIMENTAL}

All starting materials and reagents were purchased from Aldrich or Fluka without further purification. Tbfmoc-Cl and Ethyl 1-hydroxy-1H-1,2,3-triazole-4-carboxylate (HOCt) were synthesized in our laboratory. The solvents used in the reactions were dried before distillation. The Fmoc-Ub ${ }^{2-76}$ NHN(Boc)-Linker-Resin (0.0305 $\mathrm{mmol} / \mathrm{g})$ was prepared by Albachem Company using Fmoc SPPS method.

Sephadex G50 (fine, $120 \mathrm{~cm} \times 2.5 \mathrm{~cm}$ ) was used for gel filtration. The column eluted at $39 \mathrm{~mL} / \mathrm{h}$ with monitoring at 214 and $365 \mathrm{~nm}$. Amino acid analyzer equipped with an LKB 2220 Recording Integrator. Mass spectra (MS) were carried out using the electrospray method on a VG-Fisons BIO-Q instrument courtesy of VG Biotech. ${ }^{1} \mathrm{H}$ NMR spectra were recorded on Varian GEMINI 2000 (200 MHz). Specific rotations $\left([\alpha]_{D}\right)$ were measured on a optical activity AA-2000 polarimeter. HPLC was carried out using a Gilson system comprising $2 \times$ 306 solvent delivery systems, an 811 c dynamic mixer, an 805 manometric module, a 119 UV/VIS detector and a Gilson 715 software-driven gradient controller. The column used for peptide analysis was Vydac $C_{18}$ RP phase silica ( $5 \mathrm{~mm}$ spherical silica, $250 \mathrm{~mm} \times 4.6 \mathrm{~mm})$.

The general procedure for the synthesis of Tbfmoc-Met$\mathrm{OH}$ is shown in Scheme-I; the preparation, separation and purification procedure for Tbfmoc-Ub-NHNH 2 and $\mathrm{H}-\mathrm{Ub}$ $\mathrm{NHNH}_{2}$ are show in Scheme-II.

Synthesis of Tbfmoc-Met-OBu ${ }^{-t}$ (2): H-Met-OBu ${ }^{-t}(2.6$ $\mathrm{g}, 12.6 \mathrm{mmol})$, Tbfmoc-Cl (1 in Scheme-I, $6.13 \mathrm{~g}, 1335 \mathrm{mmol})$ and N,N-dimethylaniline (1.68 mL, $13.2 \mathrm{mmol}$ ) were dissolved in dichloromethane $(120 \mathrm{~mL})$ and stirred in the absence of

$$
\begin{aligned}
& \text { Fmoc- } \mathrm{Ub}^{2-76}-\mathrm{NHN}(\mathrm{Boc}) \text {-Linker-Resin } \underset{\mathbf{4}}{\stackrel{\text { DMF }}{\longrightarrow}} \mathrm{H}-\mathrm{Ub}^{2-76}-\mathrm{NHN}\left(\begin{array}{c}
\mathbf{5} \\
\mathbf{5}
\end{array}\right.
\end{aligned}
$$

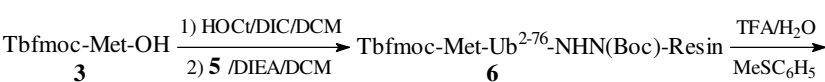

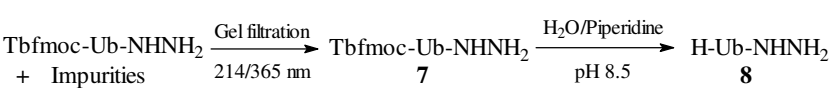

Scheme-II: Synthesis and purification of $\mathrm{H}-\mathrm{Ub}-\mathrm{NHNH}_{2}$

light at room temperature for $24 \mathrm{~h}$. The solution was washed with aq. $\mathrm{HCl}(0.2 \mathrm{M}, 30 \mathrm{~mL} \times 2 \mathrm{~mL})$, brine $(50 \mathrm{~mL} \times 3 \mathrm{~mL})$, dried with $\mathrm{Na}_{2} \mathrm{SO}_{4}$ and evaporated to remove the solvent. The residue was dissolved in $\mathrm{CH}_{2} \mathrm{Cl}_{2}-\mathrm{Et}_{2} \mathrm{O}(1: 9,30 \mathrm{~mL})$ and kept in a refrigerator. The pale white cotton-like solid product 2 was collected by filtration $(6.06 \mathrm{~g}, 76 \%)$. m.p. $150-152{ }^{\circ} \mathrm{C}$. $[\alpha]_{\mathrm{D}}{ }^{20}-16.0^{\circ},[\alpha]_{546^{20}}-20.1^{\circ}\left(\mathrm{c} 1.03, \mathrm{CH}_{2} \mathrm{Cl}_{2}\right) .{ }^{1} \mathrm{H}$ NMR $(200$ $\left.\mathrm{MHz}, \mathrm{CDCl}_{3}\right)$ 7.5-8.9 (16H, m, aromatic), $5.19(2 \mathrm{H}, \mathrm{d}, J=8.5 \mathrm{~Hz})$, 4.5-4.7 (2H, m, CH, NH), $4.30(1 \mathrm{H}, \mathrm{m}, \mathrm{CH}), 2.38(2 \mathrm{H}, \mathrm{t}, J=$ $\left.7.0 \mathrm{~Hz}, \mathrm{CH}_{2}\right), 2.03\left(3 \mathrm{H}, \mathrm{s}, \mathrm{SCH}_{3}\right), 1.80\left(2 \mathrm{H}, \mathrm{m}, \mathrm{CH}_{2}\right), 1.45(9 \mathrm{H}$, $\mathrm{s}, t$-Bu). HRMS 627.24385 [ $\mathrm{C}_{40} \mathrm{H}_{37} \mathrm{NO}_{4} \mathrm{~S}$ requires 627.24433].

Synthesis of Tbfmoc-Met-OH (3): A mixture of 2 (5.0 $\mathrm{g}, 7.96 \mathrm{mmol})$, methyl sulphide $(3 \mathrm{~mL})$ and water $(5 \mathrm{~mL})$ in trifluoroacetic acid (TFA, $30 \mathrm{~mL}$ ) was stirred at r.t. in the absence of light under $\mathrm{N}_{2}$ for $1 \mathrm{~h}$, then evaporated to remove the solvents. The residue was dissolved in DCM $(80 \mathrm{~mL})$, then $\mathrm{Et}_{2} \mathrm{O}(160 \mathrm{~mL})$ was added. The pale white solid product 3 was collected by filtration $(4.36 \mathrm{~g}, 82 \%)$. m.p. $158-160{ }^{\circ} \mathrm{C} .[\alpha]_{\mathrm{D}}{ }^{20}$ $-32.69^{\circ},[\alpha]_{546}{ }^{20}-39.13^{\circ}$ (c $0.52, \mathrm{CH}_{2} \mathrm{Cl}_{2}$ ). ${ }^{1} \mathrm{H} \mathrm{NMR}(200 \mathrm{MHz}$, $\left.\mathrm{CDCl}_{3}\right)$ 7.5-8.9 (16H, m, aromatic), $5.16(2 \mathrm{H}, \mathrm{d}, J=8.5 \mathrm{~Hz}$, $\left.\mathrm{CH}_{2}\right), 4.75(1 \mathrm{H}, \mathrm{m}, \mathrm{CH}), 4.53(1 \mathrm{H}, \mathrm{m} \mathrm{NH}), 4.36(1 \mathrm{H}, \mathrm{m}, \mathrm{CH})$, $2.36\left(2 \mathrm{H}, \mathrm{t}, J=7.5 \mathrm{~Hz}, \mathrm{CH}_{2}\right), 2.00\left(3 \mathrm{H}, \mathrm{s}, \mathrm{SCH}_{3}\right), 1.82(2 \mathrm{H}, \mathrm{m}$, $\left.\mathrm{CH}_{2}\right)$. HRMS $571.18162\left(\mathrm{C}_{36} \mathrm{H}_{29} \mathrm{NO}_{4} \mathrm{~S}\right.$ requires 571.18173).

Synthesis of Tbfmoc-Ub-NHNH (7): Fmoc-Ub $^{2-76}$ NHN(Boc)-Linker-Resin (4 in Scheme-II, 650 mg, 0.0305 $\mathrm{mmol} / \mathrm{g}$ ) was mixed with of piperidine $(2 \mathrm{~mL})$ and DMF (10 $\mathrm{mL}$ ) and stirred with $\mathrm{N}_{2}$ for $20 \mathrm{~min}$ at r.t. The mixture was filtered to remove the solvents, the rest resin was washed with $\operatorname{DMF}(5 \mathrm{~mL} \times 3 \mathrm{~mL})$ and filtered to obtain $\mathrm{H}-\mathrm{Ub}^{2-76}-\mathrm{NHN}($ Boc $)-$ Linker-Resin (5).

Tbfmoc-Met-OH (3, $68 \mathrm{mg}, 0.12 \mathrm{mmol})$ was mixed with DCM $(6 \mathrm{~mL})$, then HOCt $(285 \mathrm{mg}, 0.5 \mathrm{mmol})$ and diisopropylcarbodiimide (DIC, $18 \mathrm{~mL}, 0.12 \mathrm{mmol}$ ) was added and the mixture was stirring for $25 \mathrm{~min}$ at room temperature. The H-Ub ${ }^{2-76} \mathrm{~N}$ (NHBoc)-Resin (5, $670 \mathrm{mg}$ ) and DCM/DIEA $\left(8 \mathrm{~mL} / 0.1 \mathrm{~mL}\right.$ ) were added and stirred with $\mathrm{N}_{2}$ for $2 \mathrm{~h}$, then the solution was removed by filtration. The produced TbfmocUb- NHN(Boc)-Linker- Resin (6 in Scheme-II) was washed with DMF $(5 \mathrm{~mL} \times 3 \mathrm{~mL}), \mathrm{DCM}(5 \mathrm{~mL} \times 3 \mathrm{~mL}), \mathrm{Et}_{2} \mathrm{O}(5 \mathrm{~mL}$ $\times 3 \mathrm{~mL})$, respectively, then dried to get $6(681 \mathrm{mg})$.

6 (450 mg) was mixed with TFA $(20 \mathrm{~mL}), \mathrm{H}_{2} \mathrm{O}(2.0 \mathrm{~mL})$ and thioesole $(1.0 \mathrm{~mL})$ and stirred with $\mathrm{N}_{2}$ for $2 \mathrm{~h}$. at r.t., then the solution was collected by filtration; the resin was washed with TFA $(3 \mathrm{~mL} \times 3 \mathrm{~mL})$. The combined filtrate and washing were evaporated to remove the solvents; the rest part was washed with $\mathrm{Et}_{2} \mathrm{O}(5 \mathrm{~mL} \times 3 \mathrm{~mL})$, filtered and dried to get the crude Tbfmoc-Ub-NHNH 2 (7, $175 \mathrm{mg})$.

Purification of Tbfmoc-Ub-NHNH 2 (7): The cleaved crude 7 was dissolved in $25 \%$ acetic acid solution and then 
separated with gel filtration (Sephadex G50, $5 \mathrm{~mm}$ spherical silica, $250 \mathrm{~mm} \times 4.6 \mathrm{~mm}$ ). The column was washed with $25 \%$ acetic acid; the eluted solution was detected at 214 and 365 $\mathrm{nm}$. The collected elution with strong $365 \mathrm{~nm}$ absorbance (Fig. 2) was freeze-drying to get Tbfmoc-Ub- $\mathrm{NHNH}_{2}$ (7) as a white solid (70 mg).

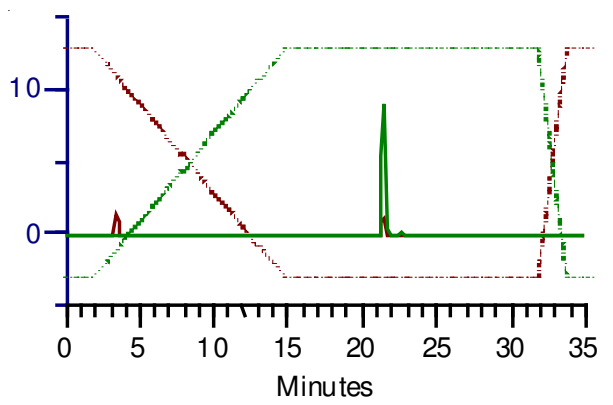

Fig. 2. HPLC of Tbfmoc-Met-OH

Preparation and identification of $\mathrm{H}-\mathrm{Ub}-\mathrm{NHNH}_{2}$ (8): A sample of $7(15 \mathrm{mg})$ was dissolved in a solution of piperidine aqueous ( $\mathrm{pH} 8.5,10 \mathrm{~mL}$ ) and sonicated for $0.5 \mathrm{~h}$, then freezedrying to get a white solid, which was washed with DCM $(2 \mathrm{~mL} \times 3 \mathrm{~mL})$ and $\mathrm{Et}_{2} \mathrm{O}(2 \mathrm{~mL} \times 3 \mathrm{~mL})$, then centrifuged and dried to get the H-Ub-NHNH 2 (8, $11 \mathrm{mg}$, Scheme-II). The purified synthetic $\mathrm{H}-\mathrm{Ub}-\mathrm{NHNH}_{2}$ showed satisfactory amino acid analysis data (Table-1), correct MS data [MS: 8579.76 Fig. 3, H-Ub-NHNH $2\left(\mathrm{C}_{378} \mathrm{H}_{632} \mathrm{~N}_{107} \mathrm{O}_{11} 7 \mathrm{~S}\right)$ requires 8579.88$]$. HPLC show a single peak with 17.1 min retention time (Fig. 3).
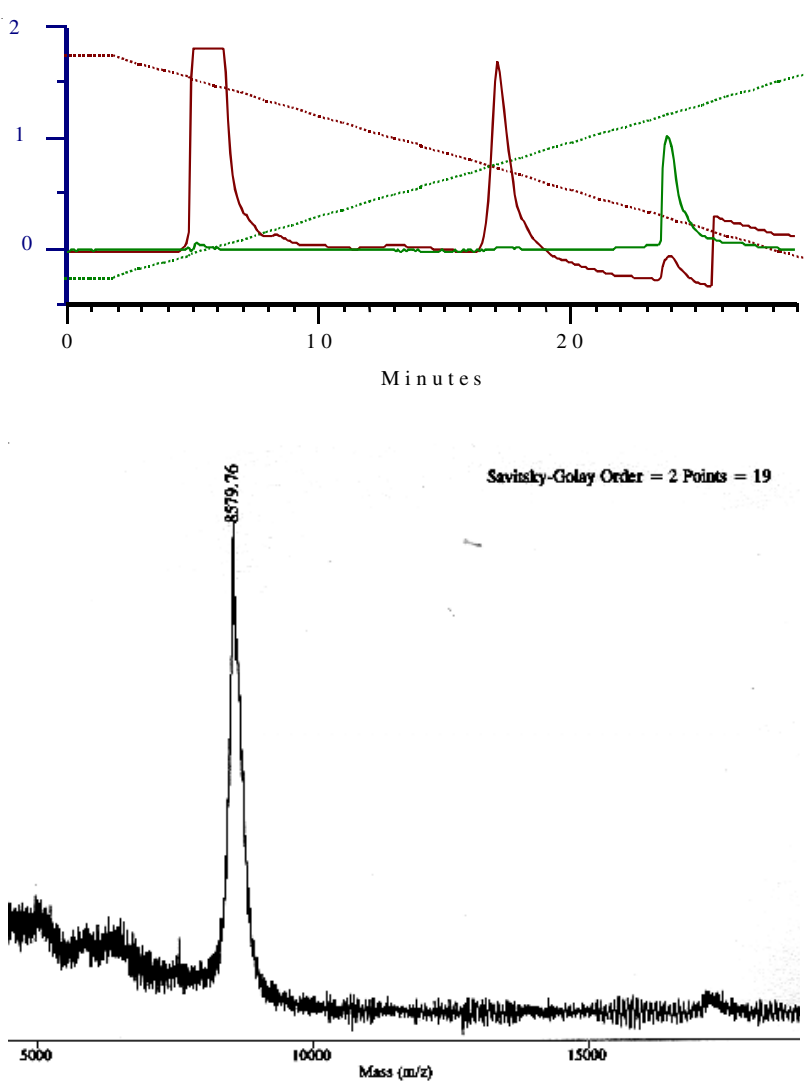

Fig. 3. HPLC (17.2 min) and MALDI-TOF-MS (8579.76; requires: 8579.88) of the synthetic $\mathrm{H}-\mathrm{Ub}-\mathrm{NHNH}_{2}$
TABLE-1

AMINO ACID (AA) ANALYSIS DATA OF H-Ub-NHNH

\begin{tabular}{|c|c|c|c|c|c|}
\hline \multirow{2}{*}{$\begin{array}{c}\text { AA } \\
\text { number }\end{array}$} & \multicolumn{2}{|c|}{ Analytical data } & \multirow{2}{*}{$\begin{array}{c}\text { AA } \\
\text { number }\end{array}$} & \multicolumn{2}{|c|}{ Analytical data } \\
\hline & $30 \mathrm{~h}$ & $45 \mathrm{~h}$ & & $30 \mathrm{~h}$ & $45 \mathrm{~h}$ \\
\hline $\operatorname{Asx}_{7}{ }^{a}$ & 6.9 & 7.04 & Met $_{1}$ & 0.83 & 0.91 \\
\hline $\mathrm{Thr}_{7}$ & 6.55 & 6.65 & $\mathrm{Ile}_{7}$ & 6.87 & 7.12 \\
\hline $\mathrm{Ser}_{3}$ & 3.08 & 2.88 & $\mathrm{Leu}_{9}$ & 9.20 & 9.43 \\
\hline $\mathrm{Glx}_{12}{ }^{\mathrm{b}}$ & 10.84 & 11.43 & $\mathrm{Tyr}_{1}$ & 0.85 & 0.83 \\
\hline $\mathrm{PrO}_{3}$ & 3.10 & 2.91 & $\mathrm{Phe}_{2}$ & 1.83 & 1.90 \\
\hline Gly $_{6}$ & 6.35 & 6.38 & $\mathrm{His}_{1}$ & 1.07 & 1.03 \\
\hline $\mathrm{Ala}_{2}$ & 2.17 & 2.18 & $\mathrm{Lys}_{7}$ & 7.00 & 7.00 \\
\hline $\mathrm{Val}_{4}$ & 4.19 & 4.25 & $\mathrm{Arg}_{4}$ & 3.97 & 3.88 \\
\hline
\end{tabular}

${ }^{\mathrm{a}}$ Asx includes Asp and Asn; ${ }^{\mathrm{b}} \mathrm{Glx}$ includes Glu and Gln.

\section{RESULTS AND DISCUSSION}

Synthesis of Tbfmoc-Met-OH (3): H-Met-OBu ${ }^{-t}$ was reacted with Tbfmoc- $\mathrm{Cl}$ (1 in Scheme-I) to produce the intermediate Tbfmoc-Met-OBu ${ }^{-t} \mathbf{2}$, which was deprotected with $\mathrm{TFA} / \mathrm{SMe}_{2}$ to remove the $t$-butyl group, then the produced Tbfmoc-Met-OH (3) was purified by recrystalization to get $\mathbf{3}$ with $62 \%$ yield. The analytical data of the synthetic TbfmocMet-OH including m.p. $158-160{ }^{\circ} \mathrm{C} .[\alpha]_{D}{ }^{20}-32.69^{\circ},[\alpha]_{546}{ }^{20}-$ $39.13^{\circ}$; HRMS 571.18162 $\left(\mathrm{C}_{36} \mathrm{H}_{29} \mathrm{NO}_{4} \mathrm{~S}\right.$ requires: 571.18173$)$; HPLC 21.4 min (Fig. 2) show the product has high purity with unchanged chiral center. The ${ }^{1} \mathrm{H}$ NMR data [7.5-8.9 (16H, m, aromatic), $5.16\left(2 \mathrm{H}, \mathrm{d}, J=8.5 \mathrm{~Hz}, \mathrm{CH}_{2}\right), 4.75(1 \mathrm{H}, \mathrm{m}, \mathrm{CH})$, $4.53(1 \mathrm{H}, \mathrm{m} \mathrm{NH}), 4.36(1 \mathrm{H}, \mathrm{m}, \mathrm{CH}), 2.36(2 \mathrm{H}, \mathrm{t}, J=7.5 \mathrm{~Hz}$, $\left.\left.\mathrm{CH}_{2}\right), 2.00\left(3 \mathrm{H}, \mathrm{s}, \mathrm{SCH}_{3}\right), 1.82\left(2 \mathrm{H}, \mathrm{m}, \mathrm{CH}_{2}\right)\right]$ confirm that the synthetic Tbfmoc-Met-OH has correct structure.

Synthesis of Tbfmoc-Ub-NHNH $\mathbf{N H}_{2}$ (7): The Fmoc-Ub ${ }^{2-}$ ${ }^{76}$-N(NHBoc)-Linker- -Resin (4 in Scheme-II, synthesized by Fmoc SPPS method) was treated with piperidine/DMF to remove the Fmoc group, the produced resin bound $\mathrm{H}-\mathrm{Ub}^{2-76}$ N(NHBoc)-Linker-Resin (5) was reacted with Tbfmoc-Met$\mathrm{OH}(3)$ using HOCt and DIC as coupling reagents to produce resin bound Tbfmoc-Ub ${ }^{1-76}-\mathrm{N}$ (NHBoc)-Linker-Resin (6), which was treated with TFA to cleave the peptide chain from the resin and the crude synthetic Tbfmoc-Ub-NHNH${ }_{2}$ was obtained.

Separation and purification of Tbfmoc-Ub-NHNH 2 (7): The crude products cleaved from the resin were separated by gel filtration. The first eluted single peak with strong $365 \mathrm{~nm}$ absorbance fraction was collected (Fig. 4) and freeze-drying to get the pure Tbfmoc-Ub-NHNH 2 (7).

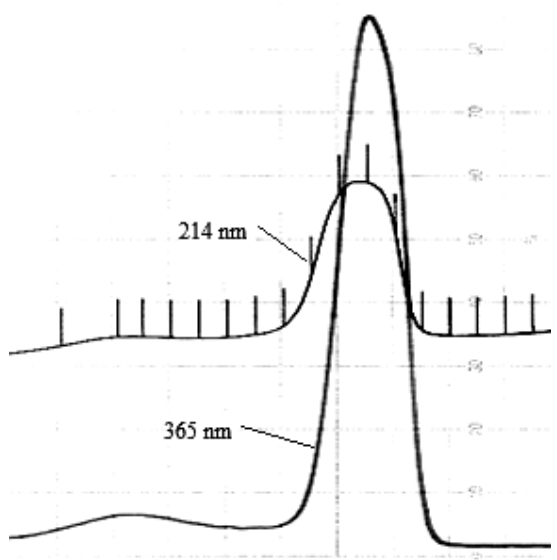

Fig. 4. Gel filtration of Tbfmoc-Ub-NHNH 2 
Preparation of $\mathbf{H}-\mathbf{U b}-\mathrm{NHNH}_{2}(\mathbf{8})$ : The purified TbfmocUb-NHNH ${ }_{2}$ (7) was treated with piperidine under $\mathrm{pH} 8.5$ condition to remove the Tbfmoc group, then freeze-drying to get solid product, which was washed with $\mathrm{Et}_{2} \mathrm{O}$, then filtered and dried with vacuum to obtain the target product $\mathrm{H}-\mathrm{Ub}-\mathrm{NHNH}_{2}$ (8). The amino acid analysis results (Table-1) confirmed that the prepared $\mathrm{H}-\mathrm{Ub}-\mathrm{NHNH}_{2}$ has correct amino acid composition and the analytical dada of $\mathbf{8}$ (HPLC $17.2 \mathrm{~min}$; MALID-TOFMS: 8579.76, $\mathrm{C}_{378} \mathrm{H}_{632} \mathrm{~N}_{107} \mathrm{O}_{117} \mathrm{~S}$ requires 8579.88. Fig. 4) show the synthetic $\mathrm{H}-\mathrm{Ub}-\mathrm{NHNH}_{2}$ has correct structure with high purity.

\section{Conclusion}

By using the synthetic new reagent Tbfmoc-Met-OH as the key building block to replace Fmoc-Met-OH for the SPPS of $\mathrm{H}-\mathrm{Ub}-\mathrm{NHNH}_{2}$ and bring the Tbfmoc group into the synthetic intermediate, an efficient method is established to simplify the product separation and purification process and overcome the purification difficulty in $\mathrm{H}-\mathrm{Ub}-\mathrm{NHNH}_{2}$ synthesis. The established method is applied for the separation and purification of the synthetic $\mathrm{H}-\mathrm{Ub}-\mathrm{NHNH}_{2}$ successfully and will be valuable for other chemical synthetic proteins.

\section{ACKNOWLEDGEMENTS}

Thanks for the financial support come from the National Natural Science Foundation of China (No. 21072116) and the Natural Science Foundation of Shandong (No. ZR2010BM040).

\section{REFERENCES}

1. D. Mukhopadhyay and H. Riezman, Science, 315, 201 (2007).

2. M. Hochstrasser, Nature, 458, 422 (2009).

3. V.G. Bhoj and Z.J. Chen, Nature, 458, 430 (2009).

4. S. Bergink and S. Jentsch, Nature, 458, 461 (2009).

5. S. Virdee, Y. Ye, D.P. Nguyen, D. Komander and J.W. Chin, Nat. Chem. Biol., 6, 750 (2010).

6. N.X. Zhang, Q.H. Wang, A. Ehlinger, L. Randles, J.W. Lary, Y. Kang, A. Haririnia, A.J. Storaska, J.L. Cole, D. Fushman and K.J. Walters, Mol. Cell, 35, 280 (2009)

7. A.R. Brown, S.L. Irving and R. Ramage, Tetrahedron Lett., 34, 7129 (1993).

8. A.R. Brown, S.L. Irving, R. Ramage and G. Raphy, Tetrahedron, 51, 11815 (1995).

9. N. Robertson and R. Ramage, J. Chem. Soc. Perkins Trans I, 8, 1015 (1999).

10. L.A. Carpino and G.Y. Han, J. Am. Chem. Soc., 92, 5748 (1970). 